University of Nebraska - Lincoln

DigitalCommons@University of Nebraska - Lincoln

USDA National Wildlife Research Center - Staff Publications
U.S. Department of Agriculture: Animal and Plant Health Inspection Service

2011

\title{
Population Estimation and Monitoring of an Endangered Lagomorph
}

Jason A. Schmidt

Texas A\&M University, jasonalanschmidt@hotmail.com

Robert A. Mccleery

Texas A\&M University

Paige M. Schmidt

Texas A\&M University, paige.m.schmidt@aphis.usda.gov

Nova. J. Silvy

Texas A\&M University, n-silvy@tamu.edu

Roel Lopez

Texas A\&M University, roel@tamu.edu

Follow this and additional works at: https://digitalcommons.unl.edu/icwdm_usdanwrc

Schmidt, Jason A.; Mccleery, Robert A.; Schmidt, Paige M.; Silvy, Nova. J.; and Lopez, Roel, "Population Estimation and Monitoring of an Endangered Lagomorph" (2011). USDA National Wildlife Research Center - Staff Publications. 1363.

https://digitalcommons.unl.edu/icwdm_usdanwrc/1363

This Article is brought to you for free and open access by the U.S. Department of Agriculture: Animal and Plant Health Inspection Service at DigitalCommons@University of Nebraska - Lincoln. It has been accepted for inclusion in USDA National Wildlife Research Center - Staff Publications by an authorized administrator of DigitalCommons@University of Nebraska - Lincoln. 


\title{
Population Estimation and Monitoring of an Endangered Lagomorph
}

\author{
JASON A. SCHMIDT, 1,2 Department of Wildlife and Fisheries Sciences, Texas AङM University, 210 Nagle Hall, College Station, TX 77840, USA \\ ROBERT A. MCCLEERY, ${ }^{3}$ Department of Wildlife and Fisheries Sciences, Texas A $\Xi M$ University, 210 Nagle Hall, College Station, TX 77840, \\ USA \\ PAIGE M. SCHMIDT, ${ }^{4}$ Department of Wildlife and Fisheries Sciences, Texas AङM University, 210 Nagle Hall, College Station, TX 77840, USA \\ NOVA J. SILVY, Department of Wildlife and Fisheries Sciences, Texas AEM University, 210 Nagle Hall, College Station, TX 77840, USA \\ ROEL R. LOPEZ, Department of Wildlife and Fisheries Sciences, Texas AEM University, 210 Nagle Hall, College Station, TX 77840, USA
}

\begin{abstract}
We conducted the most intensive estimate of the endangered Lower Keys marsh rabbit (Sylvilagus palustris hefneri) metapopulation to date using pellet surveys and capture-recapture methodology. We livetrapped 83 rabbits, evaluated 5 closed population models, and selected the model that best represented the data. We considered the variation in behavioral response model the best model and correlated $\left(r^{2}=0.913\right)$ its patch population estimates to patch pellet densities. From the prediction equation, we generated a range-wide metapopulation estimate of 317 rabbits, a western clade population of 257 rabbits, an eastern clade population of 25 rabbits, and translocated marsh rabbit populations of 35 and zero on Little Pine and Water keys, respectively. A subset of patches whose marsh rabbit subpopulations were last estimated in 1993 exhibited a $46 \%$ decline in abundance over 15 yr. Due to the low estimate of the eastern clade population, special effort should be initiated to avoid loss of genetic diversity. The prediction equation suffers from limited data at high pellet densities, patches with $\geq 5$ pellets $/ \mathrm{m}^{2}$. Future studies should investigate if the slope of the regression is indeed near 1 by sampling patches across the range of pellet densities, especially those with $\geq 5$ pellets $/ \mathrm{m}^{2}$. The equation provides managers a quick, efficient, and noninvasive method to estimate marsh rabbit abundance from pellet counts but the confidence of predicted rabbit densities from high pellet density patches is low. ๑ 2011 The Wildlife Society.
\end{abstract}

KEY WORDS capture-recapture, lagomorph, pellet count, population estimation, rabbit density, Sylvilagus palustris befneri.

The Lower Keys marsh rabbit (Sylvilagus palustris hefneri) is a subspecies of $S$. palustris endemic to the Lower Florida Keys (Fig. 1). The United States Fish and Wildlife Service (USFWS) listed the marsh rabbit as a federally endangered subspecies in 1990, primarily due to habitat loss from human activities (USFWS 1985, 1990); however, road mortality, predation, and habitat loss from woody encroachment and sea-level rise also contribute to the species' decline (Forys 1995, USFWS 1999, Perry 2006, Faulhaber et al. 2007).

The marsh rabbit uses a variety of habitats including saltmarsh-buttonwood (Conocarpus erectus) transition zones, brackish and freshwater wetlands, and coastal beach berms (Forys and Humphrey 1996; Faulhaber et al. 2006, 2008). These areas of suitable vegetation were found in patches ranging in size from $<0.1$ ha to 51.2 ha and scattered throughout 29 islands in the Lower Florida Keys (Forys and Humphrey 1996, Faulhaber 2003). Forys and

Received: 13 November 2009; Accepted: 23 May 2010

${ }^{1}$ E-mail: jasonalanschmidt@hotmail.com

${ }^{2}$ Present Address: U.S. Department of Agriculture, Animal and Plant Health Inspection Service, Wildlife Services, National Wildlife Research Center, 6100 Columbus Avenue, Sandusky, OH 44870, USA.

${ }^{3}$ Present Address: Department of Wildlife Ecology and Conservation, University of Florida, Newins-Ziegler Hall, Gainesville, FL, 326110430, USA.

${ }^{4}$ Present Address: U.S. Department of Agriculture, Animal and Plant Health Inspection Service, Wildlife Services, National Wildife Research Center, 6100 Columbus Avenue, Sandusky, OH 44870, USA.
Humphrey (1996) explicitly tested if marsh rabbits are confined to a patch (relictual population), spend most of their lives in a patch but are capable of moving between patches (metapopulation), or regularly move between patches (patchy population). Forys and Humphrey (1996) concluded that the rabbit exists as a metapopulation and the marsh rabbit population has since been cited as a metapopulation in subsequent peer-reviewed literature.

The patchy distribution of their habitat, limited funding, incomplete surveys, lack of rigorous methodologies, and low capture success have restricted the amount and quality of information on the size of the marsh rabbit metapopulation. Using unspecified methodologies on a limited number of patches, the metapopulation was loosely estimated to be 500, 259 , and 200-400 rabbits in 1976, 1984, and 1988, respectively (Howe 1988). The estimate of 100-300 adults conducted during 1991-1993 on 39 patches was generated using rabbit defecation and pellet accumulation rates (Forys 1995).

Regardless of the method used, the metapopulation estimates for the marsh rabbit have been alarmingly low and require updating. Continued and timely abundance estimates are vital for the recovery of endangered species. Wildlife managers need current population estimates to evaluate population trends and measure a population's response to management actions (Sparrow et al. 1994, Foin et al. 1998), such as prescribed fire, translocations, and predator control, which have recently been implemented to increase marsh rabbit abundance. In addition, accurate and current metapopulation estimates are required to assess the rabbit's status 
as a federally endangered species and to monitor its recovery. The requirements under the Endangered Species Act for downlisting a species (removal from an endangered status to a threatened status) often include target population sizes above which they are unlikely to become extinct in the near future (Foin et al. 1998, USFWS 2002). Recovery criteria for the marsh rabbit include demographically stable populations, distributed on a specific number and pattern of islands (USFWS 2007).

There has been a clear need for a current range-wide estimate of abundance for the marsh rabbit along with a method for monitoring the metapopulation on a regular basis. This need has been heightened by the discovery of additional marsh rabbit habitat (Faulhaber 2003). During the 1991-1993 metapopulation estimate there were 59 known marsh rabbit patches (234 ha; Forys 1995). Currently 228 patches (>800 ha) of habitat have been delineated (Faulhaber 2003). Additionally, Crouse et al. (2009) used mitochondrial DNA analysis to conclude there was a genetic division between eastern and western populations (Fig. 1). This division was not accounted for in previous metapopulation estimates and subsequent viability analyses (Forys 1995, LaFever et al. 2008). Using 2001-2003 surveys as a baseline, the USFWS documented a 7\% decline in patch occupancy each year from 2004-2007, or a $27 \%$ decline in occupancy since 2003 (USFWS 2007).

There is also a need to continue to monitor progress of the translocation of marsh rabbits (Faulhaber et al. 2006). These management efforts moved rabbits from patches with healthy subpopulations to areas of apparently suitable habitat devoid of marsh rabbits. Faulhaber et al. (2006) released 1 eastern clade female and 11 ( $5 \mathrm{M}, 6 \mathrm{~F})$ western clade marsh rabbits on Little Pine Key during October 2001-August 2002 and 7 (3 M, 4 F) western clade marsh rabbits on Water Key in June-July 2004. Both translocations were deemed successful based on high survivorship and releasesite fidelity during the battery life of the radiotransmitters (365 days and 170 days for the Little Pine Key and Water Key translocations, respectively) as well as evidence of successful reproduction (Aug 2002 and Dec 2004 on Little Pine Key and Water Key, respectively; Faulhaber et al. 2006).

Furthermore, monitoring the marsh rabbit metapopulation before and after hurricanes can provide important insight into the resiliency of the metapopulation as well as the resiliency of individual patches. Hurricanes can result in marsh rabbit mortality as researchers recorded $>71 \%$ mortality of radio-collared marsh rabbits due to Hurricane Wilma's storm surge in 2005 (N. D. Perry, Bureau of Land Management, unpublished data).

Several methods have been used to estimate lagomorph populations, including line transects, capture-recapture estimates, and pellet counts (Eberhardt et al. 1963, Krebs et al. 1987, Fa et al. 1999, Palomares 2001, Mills et al. 2005). Although pellet counts are noninvasive, efficient, cheap, and have repeatedly been used to monitor lagomorph populations, pellet counts give only an index of the population of interest (Krebs et al. 1987, Anderson 2001, Murray et al. 2002). A more rigorous method to monitor lagomorphs is to establish a correlation between lagomorph abundance and lagomorph pellet density (Wood 1988, Krebs et al. 2001,

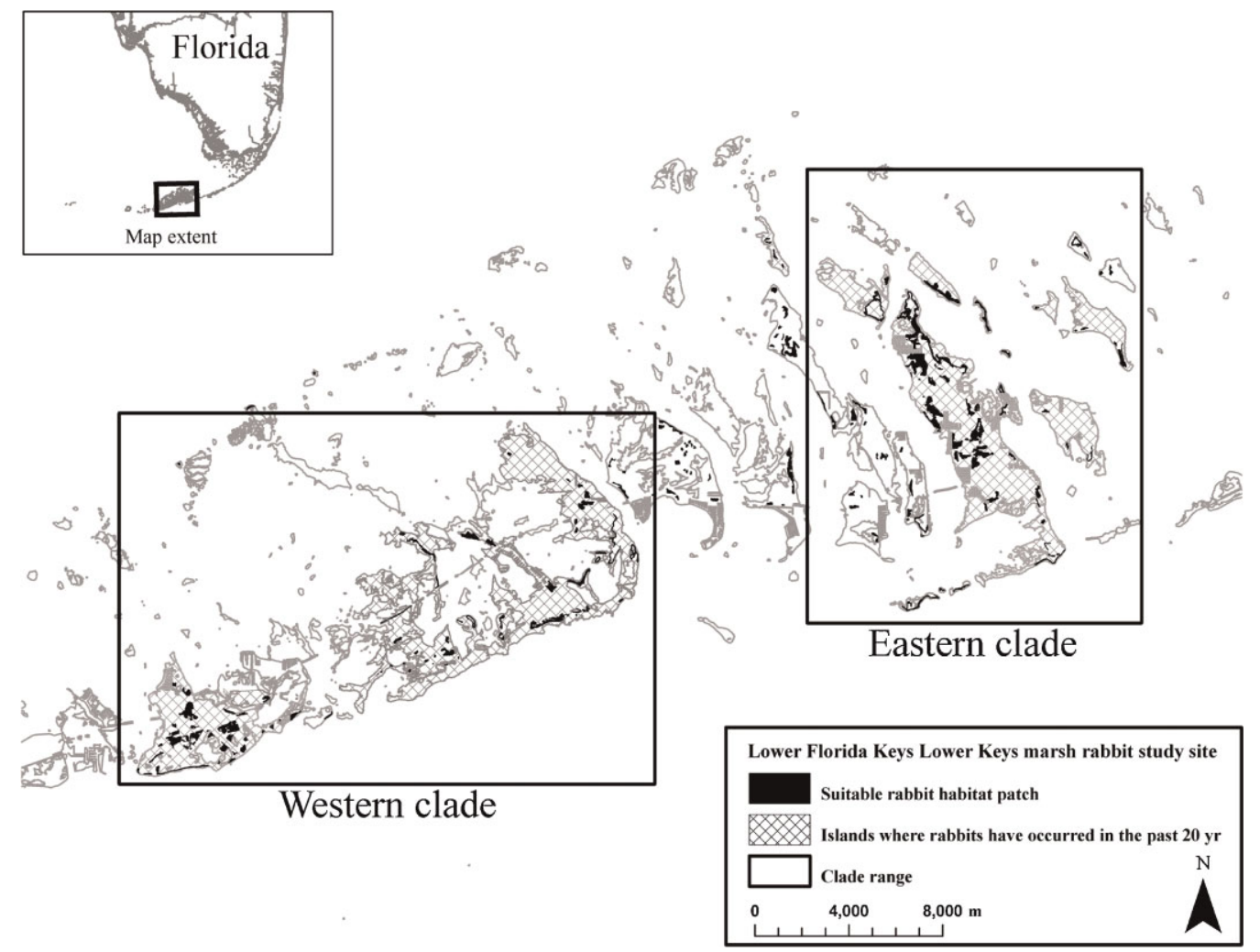

Figure 1. Lower Keys marsh rabbit study area with 228 suitable rabbit habitat patches delineated as well as western and eastern clade boundaries, Lower Florida Keys, USA, December 2007-July 2008. 
Murray et al. 2002, Homyack et al. 2006, McCann et al. 2008).

Densities estimated from capture-recapture methods likely provide more accurate population estimates than minimum number alive estimates commonly used to relate pellets to capture estimates (Homyack et al. 2006). When studies have used estimated rabbit densities from capture-recapture efforts, they did not account for varying capture probabilities (Krebs et al. 1987, Forys 1995, Forys and Humphrey 1997, Mills et al. 2005, Homyack et al. 2006). Closed-population models, incorporating time variation, behavioral response, and heterogeneity in the capture probabilities are more robust than models in which the capture probabilities are fixed (Chao and Huggins 2005).

We developed and evaluated a monitoring protocol for a rare and secretive species that can easily be implemented in $<1$ yr. Our goals were to generate a marsh rabbit metapopulation estimate, develop a low cost monitoring program for this endangered subspecies, and evaluate the success of translocations conducted $4 \mathrm{yr}$ and $6 \mathrm{yr}$ postrelease. Specifically, our objectives were to 1) systematically search for and count pellets in every habitat patch annually monitored by the USFWS, 2) generate capture-recapture subpopulation estimates for a subset of sampled patches, 3) correlate capturerecapture subpopulation estimates to pellet density, and 4) use the statistical relationship between pellets and subpopulation estimates to generate estimates for the metapopulation, each of the 2 genetically distinct clades, and the translocated populations.

\section{STUDY AREA}

The Lower Florida Keys are a group of islands forming the western end of the Florida Keys archipelago, beginning at Big Pine Key and terminating with the island of Key West (Fig. 1). This group of islands is between $23.5^{\circ}$ and $25.5^{\circ} \mathrm{N}$, several minutes north of the Tropic of Cancer (23 $26^{\prime} 22^{\prime \prime}$ $\mathrm{N})$. Their proximity to the Gulf Stream and the tempering effects of the Gulf of Mexico give the islands their mild, tropical-maritime climate (Chen and Gerber 1990). High temperatures during the summer averaged $32.2^{\circ} \mathrm{C}$ and lows averaged $26.1^{\circ} \mathrm{C}$ (National Climatic Data Center 2008). High temperatures during the winter averaged $23.9^{\circ} \mathrm{C}$ and lows averaged $18.3^{\circ} \mathrm{C}$ (National Climatic Data Center 2008). Summer rainfall averaged $11.2 \mathrm{~cm}$ and winter rainfall averaged $5.3 \mathrm{~cm}$ (National Climatic Data Center 2008).

Minute elevation changes radically influenced the vegetation of the Florida Keys. As elevation increased from zero to approximately $50 \mathrm{~cm}$ above sea level, vegetation types transitioned from red mangroves (Rhizophora mangle), to black mangroves (Avicennia gerimans), to white mangroves (Laguncularia racemosa; Ross et al. 1994). The saltmarshbuttonwood transition zone occurred approximately 50$80 \mathrm{~cm}$ above sea level (Ross et al. 1994, Faulhaber 2003). Upland areas of hammocks and pinelands occupied the land occurring above the transition zone, with elevations $2 \mathrm{~m}$ above sea level uncommon (Ross et al. 1994). Marsh rabbit habitat was defined by 3 broad land cover types: saltmarshbuttonwood transition zones, wetlands, and coastal beach berms (Forys and Humphrey 1996; Faulhaber et al. 2007, 2008). The saltmarsh-buttonwood transition zones (at the lowest elevation) included open areas of low halophytic vegetation that were inundated daily with saltwater. Dominant plant species found in this zone included glasswort (Salicornia spp.), key grass (Monanthochloe littoralis), and saltwort (Batis maritima). At slightly higher elevations, salt-tolerant plants such as sea daisy (Borrichia frutescens), seashore dropseed (Sporobolus virginicus), gulf cord grass (Spartina spartinae), saltmarsh fringe-rush (Fimbristylis castanea), saltmeadow cordgrass (Spartina patens), and saltgrass (Distichilis spicata) were present (Faulhaber et al. 2008). Buttonwood was present but not dominant, leaving the mid-elevation saltmarsh fairly free of woody species. At the higher elevations within the saltmarsh-buttonwood transition zones, buttonwood was the dominant woody species and in most marsh rabbit habitat patches only small patches of herbaceous plants composed of seashore dropseed, sea daisy, sea oxeye (Borrichia arborescens), and saltgrass were present. Wetlands occurred in low-lying areas where the water table was close to the surface or in depressions that collected precipitation. The understory of wetlands can be composed of open expanses of sedges (Cyperaceae), gulf coast spikerush (Eleocharis cellulose), or saw grass (Cladium jamaicense) and saw palmetto (Serenoa repens) with an overstory of broadleaf trees such as buttonwood, red mangrove, white mangrove, poisonwood (Metopium toxiferum), and wax myrtle (Myrica cerifera; Ross et al. 1992). During our study, small areas of gulf coast spikerush were the only herbaceous component of these wetlands. Coastal beach berm vegetation was composed of trees, shrubs, and xerophytic plants, growing on accumulations of wind-driven material situated parallel to coastlines (Florida Natural Areas Inventory 1990). Coastal beach berm woody vegetation included seagrape (Coccoloba uvifera), Jamaica dogwood (Piscidia piscipula), blolly (Guapira discolor), gumbo limbo (Bursera simaruba), seven year apple (Casasia clusiifolia), limber caper (Capparis flexuosa), blackbead (Pithecellobium guadalupense), Spanish stopper (Eugenia foetida), and Bahama nightshade (Solanum bahamense; Ross et al. 1992). Grasses and sedges also sparsely populated the berms.

\section{METHODS}

\section{Pellet Density Estimation}

We used Faulhaber's (2003) habitat patch delineations, in which he attempted to map all saltmarsh-buttonwood transition zones, brackish and freshwater wetlands, and coastal beach berms. Faulhaber (2003) employed digital orthophoto quarter quads, the Advanced Identification of Wetlands Geographic Information System (GIS) coverage (McGarry MacAulay et al. 1994), and field surveys to delineate 86 new patches (henceforth, Faulhaber patches). In addition, Faulhaber (2003) identified 142 historic patches (henceforth, historic patches) from published surveys and unpublished data and redefined their boundaries also using orthophoto quarter quads, the Advanced Identification of Wetlands GIS coverage (McGarry MacAulay et al. 1994), 
and field surveys. Of the 228 total patches delineated, we limited our survey effort to 150 patches monitored annually by the USFWS (P. T. Hughes, USFWS Ecological Services, personal communication).

We used a grid with a random start to systematically sample these 150 patches, of which 55 were Faulhaber patches and 95 were historic patches. We created a $42.8-\mathrm{km} \times 23.5-\mathrm{km}$ grid with 30-m $\times 30-m$ node spacing that encompassed the entire lower Florida Keys in ArcMap 9.2 using Hawth's Analysis Tools ver. 3.27 (Beyer 2006). We then uploaded 6,934 grid nodes with a Global Positioning System (GPS) unit. During December 2007-March 2008, we sampled 6,636 nodes $(\overline{\boldsymbol{x}}=44.2$ nodes/patch; range $=1-528)$ after excluding those located on roads, permanent bodies of water, or those inaccessible to field personnel. We placed a $1-\mathrm{m}$ radius circular plot (plot) on each node and recorded the total number of marsh rabbit pellets within the plot. We used uncleared plots because marsh rabbit pellets degrade during one season (Howe 1988) and degradation rates $<1$ yr allow for annual estimates from uncleared plots (Murray et al. 2002, Prugh and Krebs 2004). During June 2008-July 2008, we conducted follow-up pellet counts on the same plots within the 12 patches used in the capture-recapture study to increase the probability that we conducted pellet and density estimates in a closed system. Follow-up counts included recently deposited pellets as well as any old pellets that had not degraded since the initial survey (i.e., we did not clear plots at any time during our study).

We calculated mean fecal pellet density (pellets $/ \mathrm{m}^{2}$ ) for each habitat patch by dividing the sum of pellets counted in the patch by the total area sampled in the patch. We then randomly selected 12 patches containing the widest possible range of initial pellet densities for a capture-recapture study to ensure that trapping effort was spread over the range of rabbit pellet densities.

\section{Patch Subpopulation Estimation}

During May 2008-July 2008, we trapped for 5 nights in each of 12 randomly selected patches using double-door Tomahawk live traps (Model No. 107, Tomahawk, WI). We reinforced the sides and doors of traps to protect captured marsh rabbits per Faulhaber et al. (2006). We stratified trap effort by patch size by placing between 17 and 34 traps baited with apples and carrots throughout each patch. We focused on placing traps near rabbit runs, pellets, and in vegetation that would provide cover to rabbits. We set traps to capture in the evening and checked and closed all traps the following morning as suggested in the American Society of Mammalogists' Guidelines for the Capture, Handling, and Care of Mammals (Animal Care and Use Committee 1989). We restrained marsh rabbits by wrapping their hindquarters in a thin towel and placed a hood to cover their eyes to reduce stress as approved by the Texas A\&M University Institutional Animal Care and Use Committee (Animal Use Protocol No. 2007-76). We recorded mass, sex, right ear length, right hind foot length, total body length, unique markings, and presence or absence of ectoparasites on each marsh rabbit captured. We photographed each rabbit and marked captured rabbits using fur clipping as a temporary unique marker (Cox and Smith 1990).

We translated capture occasions into encounter histories and imported them into Program MARK (White and Burnham 1999). Based on rabbit biology, we selected 5 closed population models: 1) behavioral response $\left(M_{\mathrm{b}}\right)$, where probability of capture and probability of recapture were different, 2) time $\left(M_{\mathrm{t}}\right)$, where probability of capture and recapture were the same but varied by night, 3 ) behavioral response and time $\left(M_{\mathrm{tb}}\right)$, where probability of capture and probability of recapture were different and varied by night, 4) trap density and sex (Model $p$ [trap saturation] + $c[\mathrm{sex}])$, where probability of capture was a function of trap saturation and probability of recapture was a function of sex, and 5) mass (Model $p$ and $c$ [standard mass]), where probability of capture and recapture were a function of mass (Chao and Huggins 2005). We evaluated each model in Program MARK and selected the model with the lowest Akaike's Information Criterion with a second order correction for small sample size (AICc) value to generate population estimates (Burnham and Anderson 2002). Marked rabbits moved across an overgrown road approximately $4 \mathrm{~m}$ wide that divided patches 1 and 2 so we therefore combined the 2 patches into 1 patch for density estimation and subsequent regression analysis. We did not observe rabbit movement between other trapped patches, which were separated by $\geq 256 \mathrm{~m}$.

\section{Range-Wide Metapopulation Estimation}

We correlated rabbit density estimates from the best capturerecapture model to mean patch pellet densities from the follow-up surveys using regression through the origin. We chose standard linear regression through the origin because 1) it was logical to assume patches that did not contain pellets did not contain rabbits, 2) our detection probability for pellets was $>85 \%$ (Schmidt 2009), 3) the method had been shown to produce reliable population estimates (Krebs et al. 1987), and 4) we wanted to be as conservative as possible due to the endangered status of this animal. Regression through the origin can be used if there is a strong a priori reason for believing that $Y=0$ when $X=0$ (Eisenhauer 2003) and has been employed to estimate snowshoe hare densities (Lepus americanus; Krebs et al. 1987). After we obtained the regression equation using Program SPSS 15.0.1.1 (SPSS, Inc., Chicago, IL), we calculated the metapopulation, the eastern and western clade populations, and the translocated populations by inserting each of the initial range-wide pellet densities from the 150 patch survey into the regression equation and multiplying the resulting rabbit density by the specific patch area. Using SPSS, we inserted the mean patch pellet densities from the range-wide surveys into the regression equation to generate $95 \%$ confidence intervals for each patch.

\section{RESULTS}

We searched for pellets within 624 ha of habitat at 6,636 plots located within 150 marsh rabbit habitat patches from December 2007-March 2008. We found pellets in 73 patches, which resulted in a mean pellet density of 1.6 pellets $/ \mathrm{m}^{2}$ 
Table 1. Follow-up pellet counts, unique Lower Keys marsh rabbit captures per patch, patch area (ha), and model $M_{\mathrm{b}}$ (behavioral response model, where probability of capture and recapture are independent) estimates of rabbits per patch based on capture-recapture data, Lower Florida Keys, USA, May-July 2008.

\begin{tabular}{lcccc}
\hline Patch & $\begin{array}{c}\text { Mean } \\
\text { pellets/m }\end{array}$ & $\begin{array}{c}\text { Marsh rabbit } \\
\text { unique } \\
\text { captures/patch }\end{array}$ & $\begin{array}{c}\text { Patch } \\
\text { area (ha) }\end{array}$ & $\begin{array}{c}\text { Model } \boldsymbol{M}_{\mathbf{b}} \\
\text { estimates of } \\
\text { rabbits/patch }\end{array}$ \\
\hline 1,2 & 1.8 & 7 & 3.49 & 11.4 \\
5 & 0.8 & 4 & 1.08 & 6.5 \\
10 & 44.5 & 11 & 0.44 & 17.9 \\
14 & 4.7 & 12 & 1.38 & 19.5 \\
36 & 1.9 & 5 & 10.62 & 8.1 \\
90 & 0.1 & 0 & 4.56 & $\mathrm{a}$ \\
138 & 0.1 & 0 & 5.01 & $\mathrm{a}$ \\
140 & 0 & 0 & 1.34 & $\mathrm{a}$ \\
157 & 4.3 & 6 & 1.91 & 9.8 \\
160 & 19.6 & 33 & 2.82 & 53.7 \\
170 & 1.9 & 5 & 0.89 & 9.4 \\
\hline
\end{tabular}

${ }^{\text {a }}$ We were unable to calculate a Huggins model estimate because trap success $=0$.

$(\mathrm{SE}=3.5$; range $=0.003-27.2)$ for occupied patches. We found mean pellet density was initially 2.0 pellets $/ \mathrm{m}^{2}$ $(\mathrm{SE}=2.2$; range $=0.006-6.46)$ for the subset of patches selected for trapping. The follow-up surveys of these patches (Jun-Jul 2008) yielded 6.7 pellets $/ \mathrm{m}^{2} \quad(\mathrm{SE}=13.1$; range $=0-44.5)$. Additionally, we found that $52(54.7 \%)$ of the 95 historic patches and 21 (38.1\%) of the 55 Faulhaber patches contained pellets.

We trapped 12 patches for a total of 1,123 trap nights in May-July 2008. We captured 83 unique rabbits in 9 patches (Table 1). We considered Model $M_{\mathrm{b}}$ (Table 2) the best model and discarded all other models because they had AIC values $>2$ from the best model and were unlikely representations of the data (Burnham and Anderson 2002). Model $M_{\mathrm{b}}$ yielded subpopulation estimates from 6.5 to 53.7 individuals (Table 1). We developed the predictive equation from regressing follow-up pellet density survey estimates and rabbit abundance estimates through the origin, rabbits $/ \mathrm{ha}=0.947 \times$ pellets $/ \mathrm{m}^{2} \quad\left(r^{2}=0.913\right.$, $P<0.001$, SE of slope $=0.092$; Fig. 2). For regression through the origin (the no-intercept model), the coefficient of determination $\left(r^{2}\right)$ measures the proportion of the variability in the dependent variable about the origin explained by regression, which cannot be compared to the coefficient of determination for models that include an intercept.

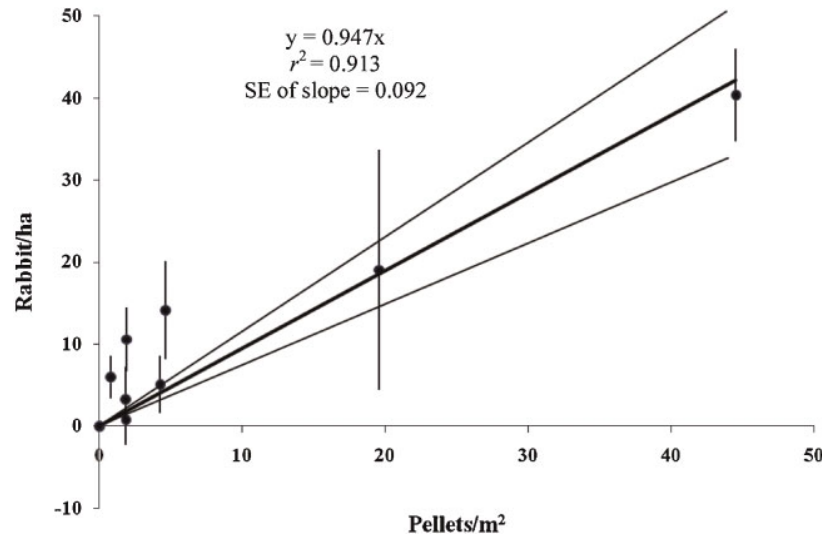

Figure 2. Linear relationship between Lower Keys marsh rabbit fecal pellet densities and rabbit densities in the Lower Florida Keys, USA, May-July 2008. We counted pellets on uncleared plots June-July 2008, and we estimated rabbit densities by capture-recapture methodology during May-July 2008. The outer, diagonal lines are the $95 \%$ mean prediction interval, and the vertical bars represent the SE for each of the rabbit density estimates. For regression through the origin (the no-intercept model), the coefficient of determination measures the proportion of the variability in the dependent variable about the origin explained by regression.

Additionally, 3 of the 9 data points for pellet densities $<5$ pellets $/ \mathrm{m}^{2}$ were clearly above the predictive space of the regression (Fig. 2), therefore underestimating rabbit abundance is a concern.

To investigate the influence of the 2 highest density subpopulations on the regression, we removed them in a stepwise manor while rerunning the regression after the removal of each point. When we removed the highest density subpopulation (44.5 rabbits/ha) we arrived at the equation, rabbits $/$ ha $=1.13 \times$ pellets $/ \mathrm{m}^{2}\left(r^{2}=0.749, P=0.001, \mathrm{SE}\right.$ of slope $=0.219)$, which increased rabbit density estimates slightly. For example, in a patch that had 20 pellets $/ \mathrm{m}^{2}$, the estimate rose from $19 \mathrm{rabbits} / \mathrm{ha}$ to $22 \mathrm{rabbits} / \mathrm{ha}$. When we removed both of the highest density subpopulations (44.5 rabbits/ha and $19.6 \mathrm{rabbits} / \mathrm{ha}$ ) from the regression, the equation became rabbits $/$ ha $=2.33 \times$ pellets $/ \mathrm{m}^{2}$ $\left(r^{2}=0.733, P=0.002\right.$, SE of slope $\left.=0.499\right)$. Removing both of the highest density subpopulations increased the rabbit density estimates considerably. Again in a patch with 20 pellets $/ \mathrm{m}^{2}$, the estimate rose from 19 rabbits/ha (the full model) to $46 \mathrm{rabbits} / \mathrm{ha}$. However, we chose the most conservative approach (the full model) in estimating rabbit abundance due to the endangered status of this species.

Table 2. Akaike's Information Criterion with a second order correction for small sample size (AICc) weights of 5 closed population models based on Lower Keys marsh rabbit capture-recapture data, Lower Florida Keys, USA, May-July 2008.

\begin{tabular}{|c|c|c|c|c|c|}
\hline Model & No. parameters & Deviance & $\mathrm{AICc}$ & $\Delta \mathrm{AICc}$ & AICc wt \\
\hline$M_{\mathrm{b}}{ }^{\mathrm{a}}$ & 2 & 522.1 & 526.1 & 0.000 & 0.7767 \\
\hline$M_{\mathrm{tb}}^{\mathrm{b}}$ & 8 & 513.5 & 529.9 & 3.723 & 0.1208 \\
\hline$p$ (trap saturation $)+c(\mathrm{sex})^{c}$ & 4 & 522.1 & 530.2 & 4.061 & 0.1020 \\
\hline$M_{\mathrm{t}}^{\mathrm{d}}$ & 5 & 530.5 & 540.6 & 14.50 & 0.0006 \\
\hline$p$ and $c$ (standard mass) ${ }^{\mathrm{e}}$ & 2 & 548.9 & 552.9 & 26.79 & 0.0000 \\
\hline
\end{tabular}

${ }^{a}$ Model $M_{\mathrm{b}}$ accounted for variation in behavioral response such as trap-shy or trap-happy individuals in capture and recapture probabilities.

${ }^{\mathrm{b}}$ Model $M_{\mathrm{tb}}$ accounted for variation in behavioral response and variation by time in capture and recapture probabilities.

${ }^{\mathrm{c}}$ Model $p$ (trap saturation) $+c(\operatorname{sex})$ accounted for trap density influencing capture probability and sex influencing recapture probability.

${ }^{\mathrm{d}}$ Model $M_{\mathrm{t}}$ accounted for daily variation in capture probability.

${ }^{\mathrm{e}}$ Model $p$ and $c$ (standard mass) accounted for the mass of the animal in the capture and recapture probability. 
Using the regression equation obtained from all 11 data points and the initial pellet survey results, we estimated the December 2007-March 2008 metapopulation was 317 individuals (95\% CI $=248-383$ ) with the 73 occupied patches averaging 1.53 rabbits/ha. We estimated the western clade population was 257 individuals (95\% CI $=199-308)$, the eastern clade population was 25 individuals (95\% CI $=22$ 33), the translocated Little Pine Key population (Faulhaber et al. 2006) was 35 individuals (95\% CI $=27-42$ ), and the translocated Water Key population (Faulhaber et al. 2006) had zero individuals $(95 \% \mathrm{CI}=0-0)$.

\section{DISCUSSION}

Pellet surveys were significantly correlated to marsh rabbit density estimates and regression through the origin generated marsh rabbit densities that were biologically reasonable $(\bar{x}=1.53$ rabbits $/$ ha for occupied patches, range $=0.06-$ 26) and similar to the previous estimate of 1.3 rabbits/ha (range $=0.86-2.26$; Forys 1995). However, regression through the origin does have a drawback as the coefficient of determination value cannot be compared to the coefficient of determination value of an ordinary least-squares model. The square of the sample correlation between observed and predicted values gives an interpretable measure of the quality of a regression through the origin but does not help in comparing regressions through the origin with ordinary least squares regressions (Eisenhauer 2003).

Our metapopulation estimate (317 individuals, 95\% $\mathrm{CI}=248-383)$ was close to the 1991-1993 estimate of 100-300 adults (Forys 1995), which suggests the marsh rabbit metapopulation has not declined since 1993. On the contrary, the marsh rabbit subpopulation suffered a $46 \%$ decline in abundance in the historic patches surveyed in both 1993 and 2007 (Schmidt 2009). Our estimate was comparable to the previous estimate due to the breadth of the survey. Our study was the most extensive estimate of the marsh rabbit metapopulation to date, based upon a sampling area $>260 \%$ the size of any previous estimate. The Faulhaber patches we surveyed did contribute to the overall metapopulation and are therefore valuable areas that support rabbits even though the proportion of patches with pellets was not as high as the historic patches we surveyed. Additionally, our metapopulation estimate was larger than the 1991-1993 estimate (100-300 individuals [Forys 1995]) because we included all rabbit age groups, whereas the previous survey included only adults. Considering the metapopulation estimate, the extent of the survey, the inclusion of all age groups in the estimate, the declines in marsh rabbit abundance on patches surveyed in 1993 and 2008, and declines indicated by USFWS occupancy surveys, a strong case can be made that the marsh rabbit metapopulation has declined since the 1991-1993 estimate.

Our results indicated large disparities between western (257 individuals) and eastern clade ( 25 individuals) marsh rabbit populations. Crouse et al. (2009) suggested these clades had the possibility of possessing distinct evolutionary potential so effort should be placed on recovering the eastern clade population if genetic diversity is to be maintained. In addition, because most (81\%) of the marsh rabbit metapopulation is composed of western clade individuals and most (82\%) of these individuals reside on the single island of Boca Chica, any event that impacts this island should be of concern.

The translocated marsh rabbit population on Little Pine Key (Faulhaber et al. 2006) appeared to be successful with an apparent 3-fold increase in rabbit numbers (12-35) over the $6 \mathrm{yr}$ from 2002 to 2008. Unfortunately, the Water Key translocation did not share the success seen on Little Pine Key. Although initially the Water Key translocation was deemed successful due to high survivorship and release-site fidelity during the battery life of the radiotransmitters (170 days) as well as evidence of successful reproduction 6 months postrelease (Faulhaber et al. 2006), we did not find evidence of a population. Water Key is smaller (92 ha) than Little Pine Key (325 ha), contains no uplands, and during high tides, only a portion of the island $(<1 \mathrm{ha})$ is not submerged (J. A. Schmidt, United States Department of Agriculture, Animal and Plant Health Inspection Service, Wildlife Services, National Wildlife Research Center, unpublished data). This fact was certainly exacerbated by Hurricane Wilma (24 Oct 2005), which could have reduced the number of rabbits on Water Key below a sustainable level.

The major limitation of our study was the paucity of patches with pellet densities $\geq 5$ pellets $/ \mathrm{m}^{2}$. The noncontiguous nature of the regression produced large gaps in the pellet density values we used in the full regression. Although we tried to sample patches with a wide range of pellet densities, most patches available for trapping contained pellet densities $<5$ pellets $/ \mathrm{m}^{2}$. Due to this limitation, the slope of the regression is acutely influenced by the 2 highest pellet density points, and unfortunately, we were unsure if the relationship between these pellet densities and the corresponding rabbit densities were representative of higher abundance sites.

An additional limitation was the possibility of underestimating rabbit subpopulations due to the 3 data points with $>6$ rabbits $/$ ha and $<5$ pellets $/ \mathrm{m}^{2}$ that were clearly above the predictive space of the regression (Fig. 2). Underestimating the subpopulation of a particular patch should not influence the management decision for that patch, as classic metapopulation dynamics declares that currently unoccupied habitat fragments (patches) may be critical for the long-term persistence of the species (Hanski 1998). Conscientious managers and biologists versed in metapopulation dynamics will not disregard patches with low or no rabbits.

Future studies should endeavor to trap rabbit patches along the full spectrum of pellet densities to give us more confidence in our prediction. There were several $(n=7)$ patches with $\geq 5$ pellets $/ \mathrm{m}^{2}$ within the high security fence of the Naval Air Station Key West's airfield. Researchers should try to obtain permission to trap these areas to acquire more data on the relationship between pellets and rabbits at high densities. Hopefully in the future, rabbit densities will increase on patches outside of this secure area allowing further research into the pellet/rabbit relationship. Addition effort should be expended trapping as many 
patches as possible within the common range of pellet densities (0.1-4.9 pellets $\left./ \mathrm{m}^{2}\right)$ to improve our confidence at these abundance levels.

\section{MANAGEMENT IMPLICATIONS}

The most appropriate equation for predicting lagomorph numbers via pellet plots should not only have high predictive power but also possess biological relevance and generality and ease of application (Murray et al. 2002). We developed and evaluated a monitoring protocol for the Lower Keys marsh rabbit that can be implemented in $<1$ yr. Our regression through the origin equation (rabbits/ha $=0.947 \times$ pellets/ $\mathrm{m}^{2}$ ) provides managers with an easily applied, predictive tool for estimating marsh rabbit densities from pellet counts in the Lower Florida Keys. The equation does not depend upon defecation rates that can vary among rabbits, as well as among days for the same rabbit (Cochran and Stains 1961). We recommend this survey method be conducted annually. Additionally, we recommend that special effort should be initiated in patches within the range of the eastern clade, if extinction is to be avoided.

\section{ACKNOWLEDGMENTS}

Our research was funded by the United States Navy, Naval Air Station Key West, Boca Chica Key, Florida, the USFWS-Ecological Services, Vero Beach, Florida, and Texas A\&M University, College Station, Texas, with the assistance of E. Barham, G. Kenny, and P. Hughes. We gratefully acknowledge the USFWS, the United States Navy, the Florida Fish and Wildlife Conservation Commission, Monroe County Public Works Department, and the numerous landowners that granted access to their property.

\section{LITERATURE CITED}

Anderson, D. R. 2001. The need to get the basics right in wildlife field studies. Wildlife Society Bulletin 29:1294-1297.

Animal Care and Use Committee. 1989. Guidelines for the capture, handling, and care of mammals as approved by the American Society of Mammalogists. Journal of Mammalogy 79:1416-1431.

Beyer, H. L. 2006. Hawth's analysis tools for ArcGIS. Version 3.26. $<$ http://www.spatialecology.com/htools>. Accessed 6 Sep 2007.

Burnham, K. P., and D. R. Anderson. 2002. Model selection and multimodel inference: a practical information-theoretic approach. Second edition. Springer-Verlag, New York, New York, USA.

Chao, A., and R. M. Huggins. 2005. Modern closed-population capturerecapture models. Pages 58-87 in S. C. Amstrup, T. L. McDonald, and B. F. J. Manly, editors. Handbook of capture-recapture analysis. Princeton University Press, Princeton, New Jersey, USA.

Chen, E., and J. F. Gerber. 1990. Climate. Pages 11-34 in R. L. Myers and J. J. Ewel, editors. Ecosystems of Florida. University of Central Florida Press, Orlando, Florida, USA.

Cochran, G. A., and H. J. Stains. 1961. Deposition and decomposition of fecal pellets by cottontails. Journal of Wildlife Management 25:432-435.

Cox, P. R., and R. H. Smith. 1990. Rodenticide ecotoxicology: assessing non-target population effects. Functional Ecology 4:315-320.

Crouse, A. L., R. L. Honeycutt, R. A. McCleery, C. A. Faulhaber, N. D. Perry, and R. R. Lopez. 2009. Population structure of the Lower Keys marsh rabbit as determined by mitocondrial DNA analysis. Journal of Wildlife Management 73:362-367.

Eberhardt, L., T. J. Peterle, and R. Schofield. 1963. Problems in a rabbit population study. Wildlife Monographs 10:1-51.

Eisenhauer, J. G. 2003. Regression through the origin. Teaching Statistics 25:76-80.
Fa, J. E., C. M. Sharples, and D. J. Bell. 1999. Habitat correlates of European rabbit (Oryctolagus cuniculus) distribution after the spread of RVHD in Cadiz Province, Spain. Journal of Zoology 249:83-96.

Faulhaber, C. A. 2003. Updated distribution and reintroduction of the Lower Keys marsh rabbit. Thesis, Texas A\&M University, College Station, USA.

Faulhaber, C. A., N. D. Perry, N. J. Silvy, R. R. Lopez, P. A. Frank, and M. J. Peterson. 2006. Reintroduction of Lower Keys marsh rabbits. Wildlife Society Bulletin 34:1198-1202.

Faulhaber, C. A., N. D. Perry, N. J. Silvy, R. R. Lopez, P. A. Frank, P. T. Hughes, and M. J. Peterson. 2007. Updated distribution of the Lower Keys marsh rabbit. Journal of Wildlife Management 71:208-212.

Faulhaber, C. A., N. J. Silvy, R. R. Lopez, D. H. LaFever, P. A. Frank, and M. J. Peterson. 2008. Diurnal habitat use by Lower Keys marsh rabbits. Journal of Wildlife Management 72:1161-1167.

Florida Natural Areas Inventory. 1990. Guide to the natural communities of Florida. Florida Natural Areas Inventory, Tallahassee, USA.

Foin, T. C., S. P. D. Riley, A. L. Pawley, D. R. Ayres, T. M. Carlsen, P. J. Hodum, and P. V. Switzer. 1998. Improving recovery planning for threatened and endangered species. BioScience 48:177-184.

Forys, E. A. 1995. Metapopulations of marsh rabbits: a population viability analysis of the Lower Keys marsh rabbit (Sylvilagus palustris hefneri). Dissertation, University of Florida, Gainesville, USA.

Forys, E. A., and S. R. Humphrey. 1996. Home range and movements of the Lower Keys marsh rabbit in a highly fragmented habitat. Journal of Mammalogy 77:1042-1048.

Forys, E. A., and S. R. Humphrey. 1997. Comparison of 2 methods to estimate density of an endangered lagomorph. Journal of Wildlife Management 61:86-92.

Hanski, I. 1998. Metapopulation dynamics. Nature 396:41-49.

Homyack, J. A., D. J. Harrison, J. A. Litvaitis, and W. B. Krohn. 2006. Quantifying densities of snowshoe hares in Maine using pellet plots. Wildlife Society Bulletin 34:74-80.

Howe, S. E. 1988. Lower Keys marsh rabbit status survey. U.S. Fish and Wildlife Service, Jacksonville Field Station, Jacksonville, Florida, USA.

Krebs, C. J., B. S. Gilbert, S. Boutin, and R. Boonstra. 1987. Estimation of snowshoe hare population density from turd transects. Canadian Journal of Zoology 65:565-567.

Krebs, C. J., R. Boonstra, V. Nams, M. O’Donoghue, K. E. Hodges, and S. Boutin. 2001. Estimating snowshoe hare population density from pellet plots: a further evaluation. Canadian Journal of Zoology 79:1-4.

LaFever, D. H., P. M. Schmidt, N. D. Perry, C. A. Faulhaber, R. R. Lopez, N. J. Silvy, and E. A. Forys. 2008. Use of a population viability analysis to evaluate human-induced impacts and mitigation for the endangered Lower Keys marsh rabbit. Human-Wildlife Conflicts 2:260-269.

McCann, N. P., R. A. Moen, and G. J. Niemi. 2008. Using pellet counts to estimate snowshoe hare numbers in Minnesota. Journal of Wildlife Management 72:955-958.

McGarry MacAulay, G., T. J. Leary, F. J. Sargent, M. M. Colby, E. J. Prouty, and C. A. Friel. 1994. Advanced Identification of wetlands in the Florida Keys, final report. Florida Department of Environmental Protection, Division of Marine Resources, Florida Marine Research Institute, Marathon, USA.

Mills, L. S., P. C. Griffin, K. E. Hodges, K. McKelvey, L. Ruggiero, and T. Ulizio. 2005. Pellet count indices compared to mark-recapture estimates for evaluating snowshoe hare density. Journal of Wildlife Management 69:1053-1062.

Murray, D. L., J. D. Roth, E. Ellsworth, A. J. Wirsing, and T. D. Steury. 2002. Estimating low-density snowshoe hare populations using fecal pellet counts. Canadian Journal of Zoology 80:771-781.

National Climatic Data Center. 2008. Climate-radar data inventories / Locate Station / Search, Key West Boca Chica Airport. <http://www4. ncdc.noaa.gov/cgi-win/wwcgi.dll?wwDI StnSrch $\sim$ StnID 10013247>. Accessed 3 Oct 2008.

Palomares, F. 2001. Comparison of 3 methods to estimate rabbit abundance in a Mediterranean environment. Wildlife Society Bulletin 29:578585.

Perry, N. D. 2006. Lower Keys marsh rabbit and the silver rice rat: steps towards recovery. Thesis, Texas A\&M University, College Station, USA.

Prugh, L. R., and C. J. Krebs. 2004. Snowshoe hare pellet-decay rates and aging in different habitats. Wildlife Society Bulletin 32:386-393.

Ross, M. S., J. J. O’Brien, and L. J. Flynn. 1992. Ecological site classification of Florida Keys terrestrial habitats. Biotropica 24:488-502. 
Ross, M. S., J. J. O’Brien, and L. D. S. Sternberg. 1994. Sea-level rise and the reduction in pine forests in the Florida Keys. Ecological Applications 4:144-156.

Schmidt, P. M. 2009. Metapopulation ecology and recovery of the Lower Keys marsh rabbit. Dissertation, Texas A\&M University, College Station, USA.

Sparrow, H. R., T. D. Sisk, P. R. Ehrlich, and D. D. Murphy. 1994. Techniques and guidelines for monitoring neotropical butterflies. Conservation Biology 8:800-809.

U.S. Fish and Wildlife Service. 1985. Endangered and threatened wildlife and plants; notice of findings on two petitions, and of review of two species. Federal Register 50:35272.

U.S. Fish and Wildlife Service. 1990. Endangered and threatened wildlife and plants; endangered status for the Lower Keys rabbit and threatened status for the Squirrel Chimney cave shrimp. Federal Register 55:2558825591.
U.S. Fish and Wildlife Service. 1999. South Florida multi-species recovery plan. United States Fish and Wildlife Service. Atlanta, Georgia, USA.

U.S. Fish and Wildlife Service. 2002. Delisting a species, section 4 of the Endangered Species Act. United States Fish and Wildlife Service, endangered species program, Arlington, Virginia, USA.

U.S. Fish and Wildlife Service. 2007. Lower Keys marsh rabbit (Sylvilagus palustris hefneri) 5-year review: summary and evaluation. U.S. Fish and Wildlife Service. Vero Beach, Florida, USA.

White, G. C., and K. P. Burnham. 1999. Program MARK: survival estimation from populations of marked animals. Bird Study 46 (Suppl): 120138.

Wood, D. H. 1988. Estimating rabbit density by counting dung pellets. Australian Wildlife Research 15:665-671.

Associate Editor: Amy J. Kuenzi. 